\title{
Environmental impacts of everyday mobility in Andalusia (Spain): towards a sustainable scenario?
}

\author{
A. L. Grindlay ${ }^{1}$, E. Molero ${ }^{1}$, C. Miralles-Guash ${ }^{2}$ \& C. Lizárraga ${ }^{3}$ \\ ${ }^{I}$ Department of Urban and Regional Planning, \\ University of Granada, Spain \\ ${ }^{2}$ Department of Geography, Universitat Autònoma de Barcelona, Spain \\ ${ }^{3}$ Department of Applied Economics, University of Granada, Spain
}

\begin{abstract}
The contribution of transportation to environmental contamination is generally accepted to be approximately $30 \%$. However, the various modes of transportation are not equal in their contribution. It is important to analyse the modal split in an effort to determine the degree of contribution and each mode's impact on overall environmental contamination in order to create sustainable mobility plans and solutions. Without a clear understanding of the impact that specific forms of transport represent, current and future plans may not provide adequate solutions for sustainability and may, indeed, prove to be severely lacking. Employing a methodology used in another area (Catalonia, Spain) this paper analyses the modal split in Andalusia, Spain, based on data from the Social Mobility Survey in Urban Regions of Andalusia 2011, exploring the territorial urban patterns and the motivational category that causes them, in order to determine the effect of the travel requirements of the population and the inherent contribution this has to the emission of greenhouse gasses and the consequent impact on environmental contamination. It also discusses the different mobility scenarios proposed in the current Sustainable Urban and Metropolitan Mobility Plans in Andalusia and their expected trends, concluding that the measures currently proposed may be considered insufficient to change the model of mobility in the metropolitan areas of Andalusia.
\end{abstract}

Keywords: mobility, environment, urban transportation, urban patterns, Andalusia. 


\section{Introduction}

As has been shown by the Intergovernmental Panel on Climate Change, transport has a significant role (14\%) in the total anthropogenic Greenhouse Gas (GHG) emissions [1].

Different transport modes have a different contribution to these emissions. Some, such as walking or cycling, do not favour the increase of GHG however, road transport, especially the private car, provides significant amounts of emissions in relation to fossil fuel energy used.

Such disparities mean it is crucial to analyse the modal split of travel, in order to understand the contribution of transport to global warming $[2,3]$.

The aim of this article is to analyse the contribution that different modes of transport have on all journeys in Andalusia, one of the autonomous communities of Spain.

The analysis of the modal structure has been carried out based on the data presented by the Social Mobility Survey in Urban Regions of Andalusia 2011 [4]. This is a source of basic information on travel in the region. Such a perspective allows an evaluation of the overall contribution of the most contaminating modes of transport related to the modal distribution of all forms of transport including walking and cycling. At the same time, it enables the study of the contribution of modes of transport to climate change from the different urban models and the social structure of transport demand.

\section{Transportation: an extremely contaminating activity}

Within the academic community there is a wide consensus of opinion regarding the fact that transportation contributes considerably to raising the levels of harmful elements in the environment, particularly in the consumption of fossil fuels and in the emission of greenhouse gases, responsible for climate change on both a local and a global scale $[5,6]$. A certain unanimity begins to exist around the idea that the contribution of transport to environmental pollution cannot solely be reduced based on technological advances. It is also necessary to turn to territorial strategies that directly affect mobility models [7, 8] and, in particular, to the modal distribution of journeys in urban and metropolitan zones, as not all means of transport contribute in the same way either to energy consumption or the emissions of harmful gases.

Transportation is the major fossil fuel energy consumer, constituting more than $35 \%$ of the total fuel demand in Europe [9]. In Spain the situation is even more extreme. The final sectorial energy demand of transportation is $40 \%$, far greater than industry $(25 \%)$, residential $(18.7 \%)$, services $(12.1 \%)$ and miscellaneous (4.2\%) [10]. In Andalusia, the transport sector consumption is more in line with the rest of Europe (35.8\%), followed by industry (30.4\%), residential $(16.4 \%)$, services $(9.5 \%)$ and miscellaneous $(7.9 \%)$ [11].

However, energy consumption is not equal for all the means of mechanized transport. On the contrary, whilst the bicycle has a consumption of 0.8 million 
joules per person per kilometre, collective transport has more than 2 million and private transport exceeds 4 million joules per person per kilometre [12].

At the same time, road transport has a less efficient energy consumption than other means, since to carry out the same task (which is measured in passenger kilometre) transport by road consumes some 23 equivalent grams of petroleum per passenger kilometre, whereas by rail this rate drops to a level of 11 grams [13].

A very direct relationship exists between consumed energy and $\mathrm{CO}_{2}$ emissions.

Transport by road, besides consuming more equivalent tons of petroleum, also emits more greenhouse gases, reaching proportions of more than $70 \%$ of emissions both in domestic transport and in the overall total. Such figures arise from the extensive and increasing use in recent years of the transport modes that have a higher consumption (e.g. private car) and an occupation of people per vehicle that, in no case, exceeds an average of 1.22 [14].

Moreover, as can be seen in existing consumption data, as opposed to the emissions from the domestic and industrial sector, emissions derived from transportation have increased most rapidly. In Spain, between 1990 and 2000, the $\mathrm{CO}_{2}$ emissions from transport have increased from 58 to 85 million tons annually, or $48 \%$ in just a decade. A large part of this increase has been parallel to economic and social development, to the improvement of the transport infrastructures and the growth of metropolitan zones [15]. Therefore, in the paradigm of sustainability promoted by European transport policy, the challenge is to disassociate the growing rates of motorization from the general growth of the economy [9].

\section{Mobility surveys as a source of information to evaluate climate change due to transportation}

In order to evaluate the contribution of the transport sector to the rates of energy use and atmospheric contamination, data from vehicles are usually used. However, these sources of information are centred on a single mode of transport, and cannot evaluate the contribution of the sector as a whole. This is only possible if this is estimated in relation to the models of mobility in conjunction with the journeys undertaken by the population. It is essential to introduce sources of information where all journeys and all means of transport are taken into consideration. This article analyses the modal distribution of the mobility of the Andalusian population in their most representative areas, including all the motives and means of transport based on The Social Survey 2011: Mobility in the urban regions of Andalusia [4], taking as a methodological reference earlier studies in Catalonia [16]. This approach enables an evaluation of the most contaminating modes of transport in relation to the other modes, the areas where they are most frequently used and the activities that they allow to be undertaken. Simultaneously, it emphasizes the fact that it is not mobility that causes $\mathrm{CO}_{2}$ emissions, but the use of certain modes of transport, in particular, the private car.

The Social Survey 2011: Mobility in the urban regions of Andalusia presents a general overview of the dynamics and models of physical mobility of the population, focusing on the intense mobility that is developing in urban areas. In order to demarcate these areas, new "urban regions" are being defined, situated on 
the metropolitan areas of Almeria, Bahia de Cadiz-Jerez, Campo de Gibraltar, Cordoba, Granada, Huelva, Jaen, Malaga and Seville. These zones include 221 municipalities in which live approximately $70 \%$ of the population of Andalusia (a little over 6 million people).

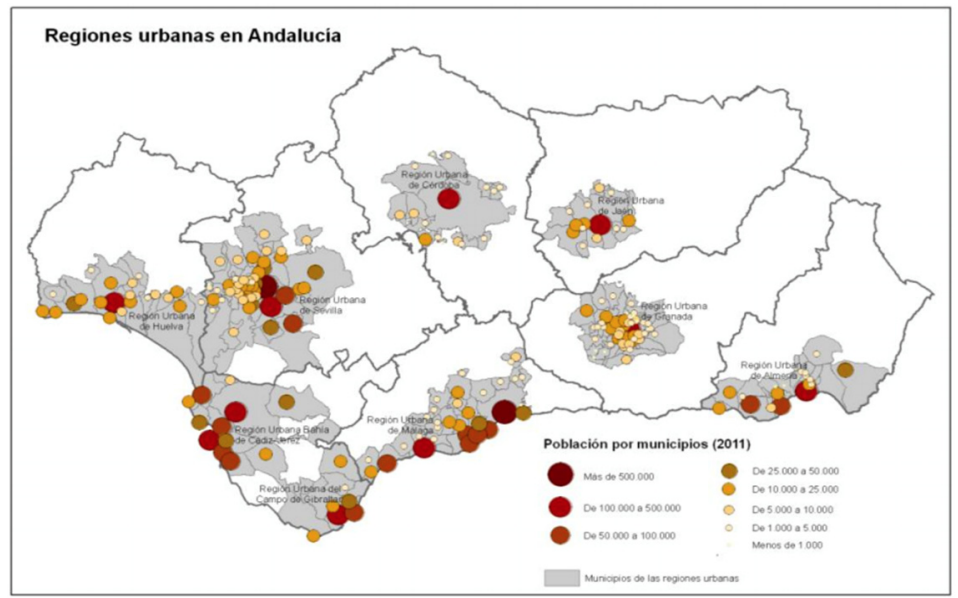

Figure 1: Urban regions in Andalusia and their municipalities' population [4].

The survey was carried out on 5,767 people of 16 years and older between the months of September and November 2011, taking account of some 18,000 journeys. It provides information on the journeys which occur at different times (working day and weekend) and which are linked to different spatial spheres (journeys within urban regions and beyond the province of residence). The results of the survey provide, from the perception of those surveyed, information on the number of journeys made, the motive for which each was made, the mode of transport used, the departure time and the time taken for each journey [4].

\section{The environmental issue of transportation in Andalusia according to modal distribution}

The modal distribution of the journeys of a community is the principal reference of the contribution of transportation to environmental pollution. The use of the different means of transport in the journeys of the population of Andalusia is analysed according to the differences of density which distinguish the type of urban areas, and from the occupational-personal category of the motives that cause them.

\subsection{The means of transport used in Andalusia}

As mentioned above, it is clear that the utilization of the different means of transport is not unconnected with $\mathrm{CO}_{2}$ emissions, due to their unequal contribution. Thus it is essential to use the information provided by the mobility 
survey regarding the levels of use of the different means of transport in Andalusia, in all journeys.

Over 13.5 million journeys are made per working day. According to the survey the private car, together with other means of private motorized transport are used in $79.3 \%$ of journeys. This is followed in importance by travel on foot or less commonly by bicycle, with $13.1 \%$ jointly and finally by public transport which is used for almost $8 \%$ of journeys. This result is consistent with the data extracted from the Population Census 2001, as both sources offer the same message: the unquestionable protagonism of the private means of transport, principally the car, to go to work, and the maintenance of this tendency over the last ten years.

These data, as a whole, indicate that the forms of transport that contribute most to atmospheric pollution are those most utilized by the Andalusian population: almost $80 \%$ of the population use private motorized transport.

\subsection{Transportation does not pollute in all urban areas in the same way}

As many authors have already shown [17-24] the type of urban settlement where individuals live principally affects their behaviour in relation to their journeys and the means chosen for them. The territory of urban agglomerations of intense mobility in Andalusia were divided, according to their urban characteristics, into compact or dispersed, subsequently creating an intermediary stratus, to account for an ambiguous territory in which it is difficult to demarcate the territorial considerations.

One of the advances in the territorial approach of this survey is in relation to the definition of population density in the territory. For its calculation, the population was taken from each of the census sections in which those surveyed were living and was placed in relation to its particular residential surface use. The following intervals of population density were consequently delimited:

- Compact zone (more than 5,000 inhabitants $/ \mathrm{km}^{2}$ )

- Intermediate zone (from 3,000 to 5,000 inhabitants $/ \mathrm{km}^{2}$ )

- Dispersed zone (less than 3,000 inhabitants $/ \mathrm{km}^{2}$ )

In broad strokes it is interesting to extract a series of data to contextualize the mobility analysis. The target population of this survey is formed by people of 16 years and older who live in family homes within the municipalities that compose the urban regions of Andalusia, which involves a total of five million people. Of these, more than $78.5 \%$ of the total resides in compact zones, $12 \%$ in dispersed zones and the remaining $9.5 \%$ in intermediate zones (Table 1).

The residents in the urban regions of Andalusia make an average of 3.6 journeys per day. In general, in keeping with the rate at which the zone is concentrated, the average number of its residents' journeys diminish, the length of the average journey shortens and the speed at which it is made decreases [25].

More than three quarters of these journeys (over 76\%) are made within the municipality itself (intra-municipal journeys). In contrast, inter-municipal journeys involve approximately $23 \%$ of the total. 
Table 1: Population distribution according to zone categorization in the 9 urban regions considered [4].

\begin{tabular}{|l|c|c|c|}
\hline Urban Region & \multicolumn{3}{|c|}{ Zone Type } \\
\hline & Dispersed zone & Intermediate zone & Compact zone \\
\hline Almeria & $9 \%$ & $11 \%$ & $81 \%$ \\
\hline Bahia de Cadiz-Jerez & $12 \%$ & $9 \%$ & $79 \%$ \\
\hline Campo de Gibraltar & $13 \%$ & $15 \%$ & $72 \%$ \\
\hline Cordoba & $13 \%$ & $7 \%$ & $80 \%$ \\
\hline Granada & $14 \%$ & $15 \%$ & $71 \%$ \\
\hline Huelva & $14 \%$ & $7 \%$ & $79 \%$ \\
\hline Jaen & $11 \%$ & $3 \%$ & $86 \%$ \\
\hline Malaga & $17 \%$ & $9 \%$ & $74 \%$ \\
\hline Seville & $7 \%$ & $9 \%$ & $84 \%$ \\
\hline
\end{tabular}

These results show significant differences between the urban regions, linked to the complexity of their settlement structure. Thus, in the urban region of Granada a higher percentage of inter-municipal journeys take place $(42.2 \%)$. At the other extreme is Cordoba, where only $8.7 \%$ of journeys have these characteristics.

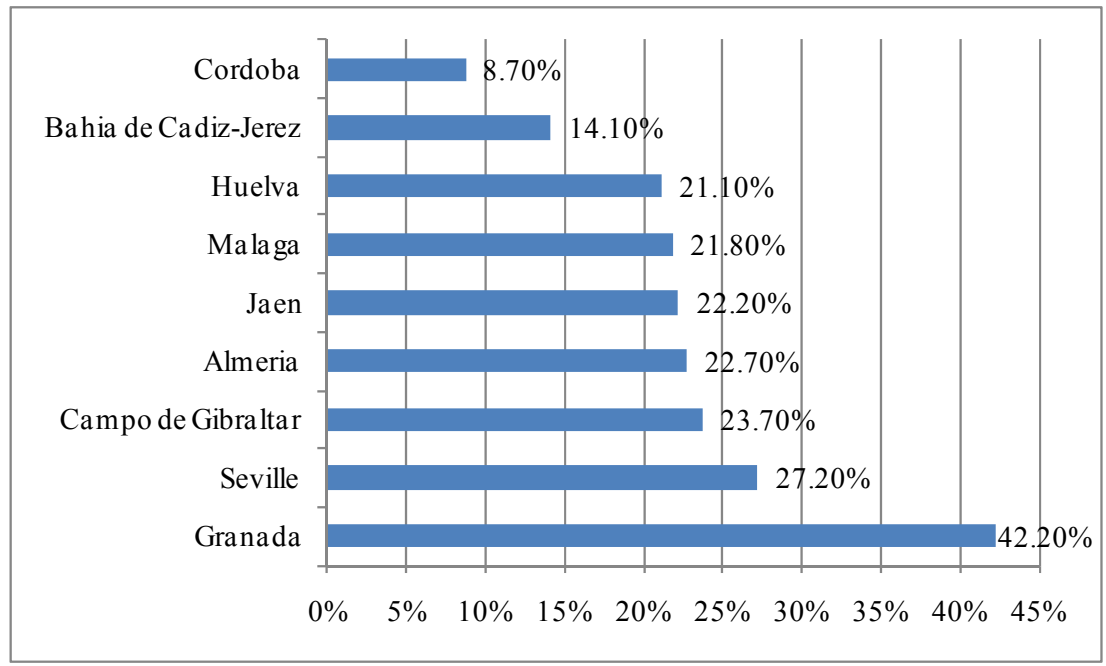

Figure 2: Inter-municipal working day journeys according to urban region [4].

The dispersed zones, where the distance travelled is higher and the journeys are quicker, the mode of transport most frequently used is the single occupancy car ( $60 \%$ of journeys), whereas in the compact zones with slower journeys of a shorter distance, the principal mode of travel is on foot ( $40 \%$ of journeys). 
The mode of transport affects and determines the journey in terms of its duration, the specific mode of transport, the physical ability to carry it out. Within the diversity of the modes of transport that are cited in the questionnaire two large groups are initially observed, private and public transport, differentiating different habits in their use according to the type of zone.

The use of public transport is much in the minority in the urban regions of Andalusia, around $6 \%$ of journeys that are made each working day are by public transport. Its use is more frequent in compact zones ( $7 \%$ of journeys), whereas in intermediate and dispersed zones it is below average (5\% and 3\% respectively). A journey may consist of a single stage, a mode of transport in which individuals are transported to the destination, or various stages in which individuals combine modes of transport to reach the final destination. Mobility in urban regions of Andalusia is characterized by the use of a sole mode of transport. Thus, $97 \%$ of journeys per working day in the urban regions of Andalusia are uni-modal.

Pluri-modality is, therefore, a minority pattern of travel for the residents in the urban regions of Andalusia. Public transport is strongly linked with this plurimodality and in journeys with several stages, more than $73 \%$ of pluri-modal journeys have public transport as the principal mode of travel. Given the criterion of allocation of principal mode of transport, this fact does not imply that these journeys are made exclusively on modes of public transport, but that in $73 \%$ of pluri-modal journeys at some stage one of the modes of public transport is more ordinarily used. That is, in the great majority of pluri-modal journeys in urban regions in Andalusia public transport is plays a part. As the zone becomes more compact, a higher frequency of the use of public transport is observed [25].

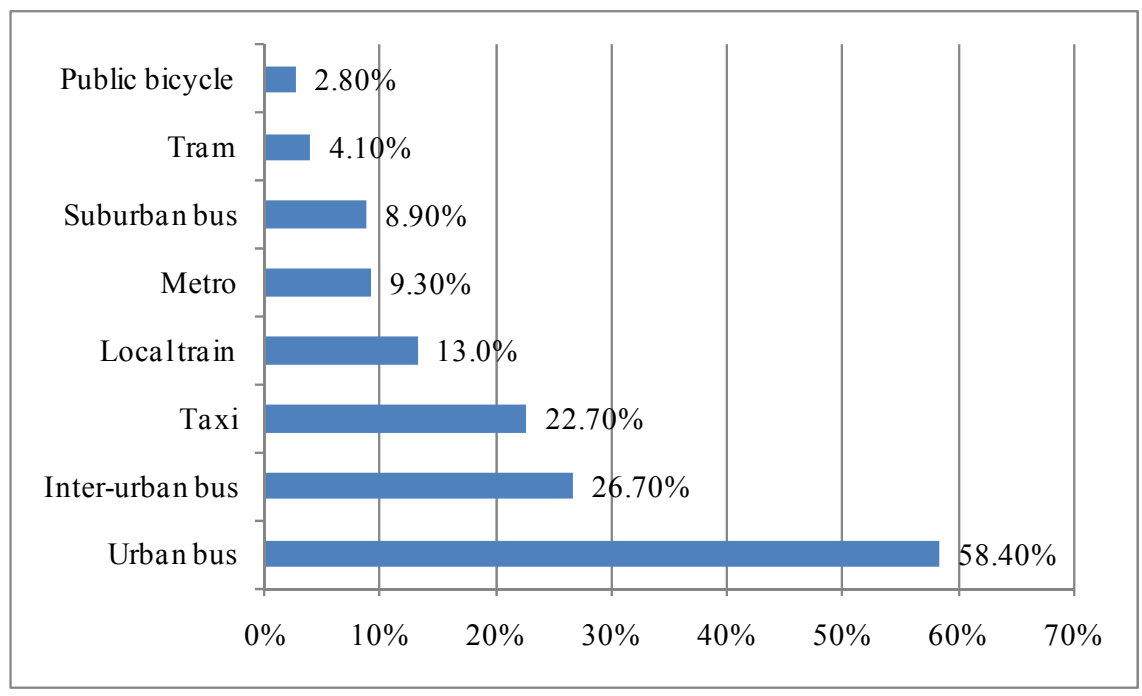

Figure 3: Mode of public transport used in urban regions by people of 16 years and over at least once a month [4]. 
The use of private transport represents the greater part of travel in the urban regions of Andalusia, around 57\% of journeys per working day are made in private vehicles. Its use is more frequent in dispersed zones (75\%) and intermediate zones $(69 \%)$, whilst in compact zones it is below average $(52 \%)$.

As the population becomes more dispersed a greater frequency of the use of private transport is observed, it also follows in the analysis by socio-demographic characteristics and motives [25-27].

These inequalities mean that the characteristics of mobility have a diverse pattern according to the place where they are situated, a fact that directly affects the environmental impacts of transport in Andalusia.

\subsection{The means of transport used depend on the motive of the journey}

The type transport used is not only dependent on the place of residence, but also on the motive that causes the journey. In Andalusia, work stands out as the principal motive $(22 \%)$, with an average duration of 21.7 minutes and an average distance of 6 kilometres. It is followed by motives of leisure, shopping and transporting children to and from school.

Work tends to generate the daily mobility of the population of Andalusia, and $79.3 \%$ of these work journeys are made in private transport. Travelling on foot or, to a lesser extent, by bicycle is the next in prevalence, with $13.1 \%$ jointly, and finally the means of public transport which are used in almost $8 \%$ of journeys. This result is consistent with the data extracted from the Population Census 2001, so the main method of individual transport for work appears unquestionably to be the private vehicle, and this tendency has continued over the last ten years [27].

This relationship between the motive and the mode changes according to the type of zone. In dispersed and compact zones private transport is mostly chosen for work, whereas in intermediate zones private transport is most frequently used to accompany another person (car sharing). Journeys for the purposes of shopping in the urban areas are usually made on foot, however for residents in dispersed or intermediate zones the mode most frequently used is the single occupancy car [25].

With respect to energy consumption and emissions of greenhouse gases, the represented data could help to clarify the zones and motives for which different modes of transport are used.

\section{Sustainability scenarios in urban and metropolitan mobility planning in Andalusia}

In recent years the Sustainable Urban or Metropolitan Mobility Plans (SUMP or SMMP) drafted in Andalusia have established different mobility scenarios to correct the current situation and their trend scenarios, with objectives quantified in $\mathrm{CO}_{2}$ emissions reductions [28].

In the case of the metropolitan area of Seville, the SMMP forecast that, if the investment in public transport continued, it was expected that the participation of public transport in urban journeys would reach $50 \%$ of the total. In the journeys between the metropolitan ring and the city centre, an increase of participation is 
sought in public transport from $15 \%$ to $34.7 \%$, and in the journeys within the metropolitan ring the objective is to reach a participation of $14.3 \%$ in public transport in 2020, which means an increase of $10 \%$ [29].

In the case of the metropolitan area of Granada, which also has a high level of centrality, the SMMP forecasts a rise in the quota of participation in public transport from $24 \%$ in 2006 to $35 \%$ predicted for the final horizon of the plan [30]. In the city centre the SUMP projected a reduction in the participation of journeys by private vehicle from the current $20 \%$ to $15 \%$ [31].

The intense mobility in the Campo de Gibraltar (the area surrounding Gibraltar) was characterized by the high number of internal journeys by private vehicle, nearing $80 \%$, and the low participation in public transport of only $5.5 \%$. In the trend scenario, mechanized mobility was increasing to $66 \%$ and journeys on foot and public transport were decreasing so the SMMP sought to increase the participation in public transport to a percentage of around $20 \%$ [32].

The Municipal Plan of Sustainable Mobility in the city of Malaga establishes an objective to reduce the private vehicle in the year 2025 to $35 \%$ for motorized urban journeys [33].

The SUMP of Jaen also puts forward objectives for the reduction of journeys by private transport to break the trend scenario that in 2018 would be in more than half the journeys by private vehicle and to increase mobility by public transport up to a participation of $16.8 \%$ of the modal share [34].

In Cordoba the SUMP [35], establishes an increase in the modal share of pedestrian mobility and the use of bicycles that entails more than half the modal share in 2020 .

Given the established data the expectations of these plans would appear to be unattainable, as all these Plans for Sustainable Mobility propose some ambitious objectives to reverse the current trend towards the increase in private motorized mobility but are limited by the existing urban patterns and depend not only on the implementation of their set of measures, but also on a change in cultural behaviour towards mobility as proposed by the Urban Sustainability Strategy of Andalusia [36].

\section{Conclusions}

Transportation is the activity that consumes the greatest fossil fuel energy and is responsible for more than a third of the emissions of greenhouse gases to the atmosphere, it is one of the sectors that has increased energy consumption the most and has emitted the highest levels of $\mathrm{CO}_{2}$ into the atmosphere. As a mode of transport, the private car, at one end of a continuum, has the greatest levels, as opposed to going on foot and by bicycle, at the other end of the continuum, which have zero or almost zero levels of contribution to environmental pollution.

These differences between the various means of transport mean that the contribution of the transport sector to the increase in the greenhouse effect depends on the percentage use of the different means of transport. That is, it is the modal share that characterizes the mobility of a territory, rather than the quantity of 
journeys that are made within it, which may influence to a greater or lesser degree the atmospheric pollution with respect to the transport sector.

From the analysis of this modal share in the autonomous community of Andalusia, based on the figures given in the Social Survey 2011: Mobility in the urban regions of Andalusia, it is demonstrated that the participation in private means of motorized transport is very much in the majority (79\%), as opposed to journeys on foot or by bicycle (13\%) and those made by public transport which scarcely make up $8 \%$ of journeys.

The results of the survey also show, similarly to other studies, how the type of zone in which individuals reside primarily affects their behaviour in relation to their journeys and the means they elect for making them. Thus in the dispersed zones the most frequently used form of transport is the single occupancy private car (60\% of journeys), whilst in the compact zones the main mode of travel is on foot $(39 \%)$. Despite its low participation, public transport is used mainly for journeys which combine different modes of transport $(73 \%)$, although the great majority of journeys are uni-modal (97\%), predominantly using private motorized transport. The use of private transport is more common in dispersed zones $(75 \%)$ and intermediate zones (69\%) whilst in compact zones it is below average (52\%).

Equally regarding motives for travel, in the principal motive, which is to go to work $(22 \%), 79.3 \%$ of these journeys are made by private vehicle, which means that the peripheral and suburban distribution of industrial estates and activity centres in our urban regions, without means of public transport, contribute substantially to the rates of environmental contamination.

Finally all the proposals contained in the Plans of Sustainable Mobility of Andalusia that try to reverse the trend scenarios with ambitious objectives are limited by the existing urban patterns and may be considered insufficient given that their success does not only depend on their fulfilment, but also on a cultural change in the population towards a new mobility culture that will require them to modify their current behaviour.

\section{References}

[1] Intergovernmental Panel on Climate Change (IPCC): Climate Change 2014: Synthesis Report. Contribution of Working Groups I, II and III to the Fifth Assessment Report of the Intergovernmental Panel on Climate Change, eds. Core Writing Team, R.K. Pachauri \& L.A. Meyer, Geneva, 2014.

[2] Kaufmann, V., Mobilité quotidienne et dynamiques urbaines. La question du rapport modal, Presses Polytechniques et Universitaires Romandes: Lausana, 2000.

[3] Hamilton C., Climate change. Handbook of Transport \& the Environment, ed. D. A. Hensher \& K. J. Button, Elsevier: Amsterdam, pp. 37-60, 2003.

[4] Instituto de Estadística y Cartografía de Andalucía (IECA). Encuesta social 2011: Movilidad en las regiones urbanas de Andalucía, 2013. Online. www.juntadeandalucia.es/institutodeestadisticaycartografia/encsocial/2011 /index.htm 
[5] Banister, D. \& Anable, J., Transport policies and climate change. Planning for climate change: Strategies for mitigation and adaptation for spatial planners, eds. S. Davouidi, J. Crawford \& A. Mehmood, Earthscan: London, pp. 55-69, 2009.

[6] Giddens, A., The politics of climate change, John Wiley and Sons Ltd.: Hoboken, 2011.

[7] Banister, D., Cities, mobility and climate change. Journal of Transport Geography, 19(6), pp. 1538-1546, 2011.

[8] Dulal, H.B., Brodnig, G. \&, Onoriose, C.G., Climate change mitigation in the transport sector through urban planning: A review. Habitat International, 35(3), pp. 494-500, 2011.

[9] European Commission (EC), White Paper 'Roadmap to a single European transport area - Towards a competitive and resource-efficient transport system' COM 144 final, 2011.

[10] Ministerio de Industria, Energía y Turismo, La Energía en España 2013, Centro de Publicaciones: Madrid, 2014. Online. www.minetur.gob.es/ energia/balances/Balances/LibrosEnergia/Energia_en_espana_2013.pdf

[11] Agencia Andaluza de la Energía, Datos Energéticos de Andalucía 2013, Junta de Andalucía: Sevilla, 2014, Online.

www.agenciaandaluzadelaenergia.es/sites/default/files/aae_memoria2013v ec.pdf

[12] International Association of Public Transport (UITP), www.uitp.org/

[13] European Environmental Agency, www.eea.europa.eu

[14] Agence de l'Environnement et de la Maítrise de l'Energie, Efficacité énergétique et environnementale des modes de transport. Coord. Eric Vidalenc. Valbonne, 2008.

[15] Miralles-Guasch, C. \& Cebollada, A., Movilidad cotidiana y sostenibilidad. Una interpretación desde la geografía humana. Boletín de Asociación de Geógrafos Españoles (AGE), 50, pp. 193-216, 2009.

[16] Miralles-Guasch, C., Las encuestas de movilidad y los referentes ambientales de los transportes. EURE, 115(38), pp. 33-45, 2012.

[17] Newman, P.W.G. \& Kenworthy, J.R., Cities and automobile dependence: An international sourcebook, Gower: Aldershot, 1989.

[18] Newman, P.W.G. \& Kenworthy, J.R., Sustainability and Cities: Overcoming Automobile Dependence, Island Press: Washington DC, 1999.

[19] Cervero, R., The Transit Metropolis: A Global Inquiry, Island Press: Washington DC, 1998.

[20] Kenworthy, J.R. \& Laube F.B., An International Sourcebook of Automobile Dependence in Cities, 1960-1990, University Press of Colorado: Boulder, 1999.

[21] Kenworthy, J.R., Transport energy use and greenhouse gases in urban passenger transport systems: A study of 84 global cities. International Sustainability Conference, Fremantle, Western Australia, 2003.

[22] Newman, P.W.G. \& Jennings, I., Cities as sustainable ecosystems: principles and practices. Island Press: Washington DC, 2008. 
[23] Pizarro, R., Urban Form and climate change: Towards Appropriate Development Patterns to Mitigate and Adapt to Global Warming. Planning for climate change: Strategies for mitigation and adaptation for spatial planners, eds. S. Davouidi, J. Crawford \& A. Mehmood, Earthscan: London, pp. 33-45, 2009.

[24] Schwanen, T., Banister, D. \& Anable, J., Scientific research about climate change mitigation in transport: A critical review, Transportation Research Part A: Policy and Practice, 10(45), pp. 993-1006, 2011.

[25] Enrique, I., La Movilidad cotidiana en las regiones urbanas de Andalucía. La movilidad según tipos de poblamiento. Documentos de Trabajo, 8, IECA: Sevilla, 2013. Online. www.juntadeandalucia.es/ institutodeestadisticaycartografia/doctrabajo/movilidad/movilidad_poblam iento.pdf

[26] Ojeda, S., La movilidad cotidiana en las regiones urbanas de Andalucía. La movilidad según distintos perfiles socioeconómicos. Documentos de Trabajo, 10. IECA: Sevilla, 2013. Online. www.juntadeandalucia.es/ institutodeestadisticaycartografia/doctrabajo/movilidad/movilidad_perfiles .pdf

[27] García, I., La Movilidad cotidiana en las regiones urbanas de Andalucía. La movilidad por razón de trabajo. Documentos de Trabajo, 9. IECA: Sevilla, 2013. Online. www.juntadeandalucia.es/institutodeestadisticaycartografia/ doctrabajo/movilidad/movilidad_trabajo.pdf

[28] Lizárraga, C. \& Grindlay, A.L., Hacia un modelo de movilidad urbana sostenible en Andalucía. Actualidad, 65. Centro de Estudios Andaluces: Sevilla, 2012.

[29] www.centrodeestudiosandaluces.es/index.php? $\bmod =$ publicaciones $\&$ cat $=1$ $8 \& \mathrm{id}=2665 \& \mathrm{i} \mathrm{da}=0 \& \mathrm{idm}=$

[30] Consejería de Obras Públicas y Transportes, Plan de Transporte Metropolitano del Área de Sevilla: Plan de Movilidad Sostenible, 2006.

[31] Consejería de Obras Públicas y Transportes, Plan de Transporte Metropolitano del Área de Granada: Plan de Movilidad Sostenible, 2008.

[32] Ayuntamiento de Granada, Plan de Movilidad Urbana Sostenible de Granada, 2012.

[33] Consejería de Obras Públicas y Transportes, Plan de Transporte Metropolitano de la Comarca del Campo de Gibraltar: Plan de Movilidad Sostenible, 2007.

[34] Ayuntamiento de Málaga, Plan Municipal de Movilidad Sostenible, 2011.

[35] Ayuntamiento de Jaén, Plan de Movilidad Urbana Sostenible de Jaén, 2013.

[36] Ayuntamiento de Córdoba, Plan de Movilidad Urbana Sostenible de Córdoba, 2011.

[37] Consejería de Medio Ambiente, Estrategia Andaluza de Sostenibilidad Urbana, Junta de Andalucía: Sevilla, 2011. Online. www.juntadeandalucia.es/medioambiente/portal_web/web/temas_ambient ales/medio_ambiente_urbano/documento_easu.pdf 